Note

\title{
Automatic controller to water plants
}

\author{
Leonardo Oliveira Medici ${ }^{1}$; Hermes Soares da Rocha ${ }^{2}$; Daniel Fonseca de Carvalho²; Carlos \\ Pimentel $^{3}$; Ricardo Antunes Azevedo ${ }^{4 *}$ \\ ${ }^{1}$ UFRRJ - Depto. de Ciências Fisiológicas, Rod. BR 465, km 7 - 23890-000 - Seropédica, RJ - Brasil. \\ ${ }^{2} U F R R J$ - Depto. de Engenharia. \\ ${ }^{3}$ UFRRJ - Depto. de Fitotecnia. \\ ${ }^{4}$ USP/ESALQ - Depto. de Genética, Av. Pádua Dias, 11, C.P. 83 - 13400-970 - Piracicaba, SP - Brasil. \\ *Corresponding author < raazeved@esalq.usp.br>
}

\begin{abstract}
Despite the massive demand of water for plant irrigation, there are few devices being used in the automation of this process in agriculture. This work evaluates a simple controller to water plants automatically that can be set up with low cost commercial materials, which are large-scale produced. This controller is composed by a ceramic capsule used in common domestic water filters; a plastic tube around $1.5 \mathrm{~m}$ long, and a pressostate used in domestic washing machines. The capsule and the pressostate are connected through the tube so that all parts are filled with water. The ceramic capsule is the sensor of the controller and has to be placed into the plant substrate. The pressostate has to be placed below the sensor and the lower it is, the higher is the water tension to start the irrigation, since the lower is the pressostate the higher is the water column above it and, therefore, the higher is the tension inside the ceramic cup to pull up the water column. The controller was evaluated in the control of drip irrigation for small containers filled with commercial organic substrate or soil. Linear regressions explained the relationship between the position of pressostate and the maximum water tension in the commercial substrate $(p<0.0054)$ and soil $(p<0.0001)$. Among the positions of the pressostate from 0.30 to $0.90 \mathrm{~m}$ below the sensor, the water tension changed from 1 to $8 \mathrm{kPa}$ for commercial substrate and 4 to $13 \mathrm{kPa}$ for the soil. This simple controller can be useful to grow plants, applying water automatically in function of the water tension of the plant substrate.
\end{abstract}

Key words: irrigation, water tension, automation, low cost

\section{Acionador automático para irrigar plantas}

\begin{abstract}
RESUMO: A despeito da enorme demanda por água na irrigação de plantas, existem poucos aparelhos para automação deste processo sendo usados na agricultura. Avaliou-se um acionador automático para irrigação, o qual pode ser confeccionado com materiais comerciais de baixo custo, pois são produzidos em larga escala. Este acionador é composto por uma cápsula cerâmica usada em filtros de água domésticos; um tubo plástico com cerca de um metro e meio de comprimento e um pressostato de máquinas de lavar roupas domésticas. A cápsula e o pressostato são conectados pelo tubo de forma que todo o espaço interno seja preenchido com água. A cápsula é o sensor do acionador e deve ser posicionada dentro do substrato das plantas. O pressostato deve ser posicionado abaixo do sensor e quanto mais baixo ele estiver, maior é a tensão da água que aciona a irrigação, pois quanto mais baixo estiver o pressostato, maior é a coluna de água acima do mesmo e, portanto, maior é a tensão na cápsula cerâmica para puxar para cima a coluna de água. $\mathrm{O}$ acionador foi avaliado no controle da irrigação por gotejamento em pequenos potes preenchidos com substrato orgânico comercial ou solo. Regressões lineares explicaram a relação entre a posição do pressostato e a tensão máxima no substrato comercial $(p<0,0054)$ e no solo ( $p<0,0001)$. Entre as posições do pressostato de 0,30 a 0,90 $\mathrm{m}$ abaixo do sensor, a tensão da água variou de $1 \mathrm{a}$ $8 \mathrm{kPa}$ para o substrato comercial e de 4 a $13 \mathrm{kPa}$ para o solo. Este simples acionador pode ser útil para cultivar plantas, aplicando água automaticamente em função da tensão da água no substrato das plantas.

Palavras-chave: irrigação, tensão da água, automação, baixo custo
\end{abstract}

\section{Introduction}

Water and nitrogen are two key resources considered main factors in limiting plant growth with approximately $70 \%$ of available water being used for irrigation (Medici et al., 2007; Lea and Parry, 2008, 2009; Saeed et al., 2008; Andrews et al., 2009; da Silva et al., 2009). Yet, the control of irrigation is barely precise (Souza and Folegatti, 2010). Even when automatic watering systems are used, they are commonly operated by timers, which are not sensitive to the plant requirement, but by indirect approaches in order to establish the time and the amount of water in each irrigation event. It is also quite common to see farmers using the same timer schedule regime for all plant growth stages (Moruelli et al., 2005). Obviously, there are automatic watering systems based on soil tensiometers (Smajstrla and Locascio, 1996; Calbo, 2005; Queiroz et al., 2008), plant sap flow sen-

Sci. Agric. (Piracicaba, Braz.), v.67, n.6, p.727-730, November/December 2010 
sors (Fernández et al., 2008), time domain reflectometry (Dukes and Scholberg, 2005) or near infrared spectroscopy (Santos and Kaye, 2009), but they are usually quite expensive to be used by small scale farmers. There are also less expensive automatic systems such as the modified mercury tensiometers (Medici, 1995; Luthra et al., 1997; Silva et al., 2001), which can be built up with commercial parts, but it appears that they have not been adopted in large scale by many farmers or even agronomy scientists, since they are not much cited in the literature. This work was carried out to evaluate one automatic controller for watering systems, simpler than these previously cited ones, which does not use mercury and can be set up by the farmer, using only easy and cheap to obtain commercial materials that are produced in large-scale (Medici, 2008). This simple device is adjustable and the present work is evaluating the relationship between its adjustment and the maximum water tension kept in two types of plant substrate.

\section{Material and Methods}

The evaluated watering controller was developed by Medici (2008) and is composed by a ceramic capsule used in common domestic water filters; a plastic tube around $1.5 \mathrm{~m}$ long and a pressostate used in domestic washing machines. The capsule and the pressostate are connected through the plastic tube so that the three parts are filled with water (Figure 1). The capsule is placed in the soil or other plant substrate and the pressostate is placed from 0.30 to $1.0 \mathrm{~m}$ below the level of the capsule and outside the substrate. The pressostate used in this controller is the simplest available in the market and costs around US\$ 5.00 .

This simple device allows the adjustment of the water tension by which the irrigation system is started, by placing the pressostate below the ceramic capsule at dif- ferent vertical distances (“h”) (Figure 1). So, the lower is the pressostate, the higher is the starting water tension, since the higher is the water column inside the controller to be compensated by the water tension in the substrate and ceramic capsule. The pressostate of this device is the switcher that turns on and off the pumps or electric valves of the watering systems. This pressostate keeps itself at a positive pressure equal or superior than $1 \mathrm{kPa}(0.1 \mathrm{~m}$ of water column). When the soil dries, the suction in the ceramic capsule pulls the water column above the pressostate, relieving the pressure on its diaphragm and the switch goes on; as the irrigation remains on, water enters again the capsule and pushes the diaphragm that closes the switch and irrigation stops.

The automatic controller was evaluated for drip irrigation of Coleus sp plants. They were used to accelerate the water extraction from the substrate and also because this plant species is known to wilt easily, having the potential to show any signs of water deficit. The plants exhibited continuous growth during the four months experiments and never exhibited any visual aspect of wilting.

In the first experiment, a commercial substrate composed mainly by pinus husks, expanded vermiculite, peat and organic compost, was used. In a second experiment, samples from the surface layer $(0-0.2 \mathrm{~m})$ of a Typic Hapludult, $\left(730,200\right.$ and $70 \mathrm{~g} \mathrm{~kg}^{-1}$ of sand, clay and silt, respectively) were used. Plants were cultivated in rectangular pots $(0.35 \times 0.14 \times 0.15 \mathrm{~m})$ in Seropédica, state

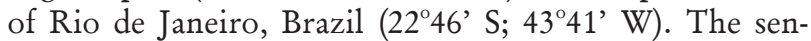
sor of the controller (the ceramic capsule) was placed in the middle of substrate and its pressostate was coupled to the electromagnetic valve of the drip irrigation.

The ceramic capsule used was the "Vela Pozzani" ref. 81011 (Inds. Francisco Pozzani S.A., Jundiaí-SP, Brasil). The pressosate used was the "pressostato

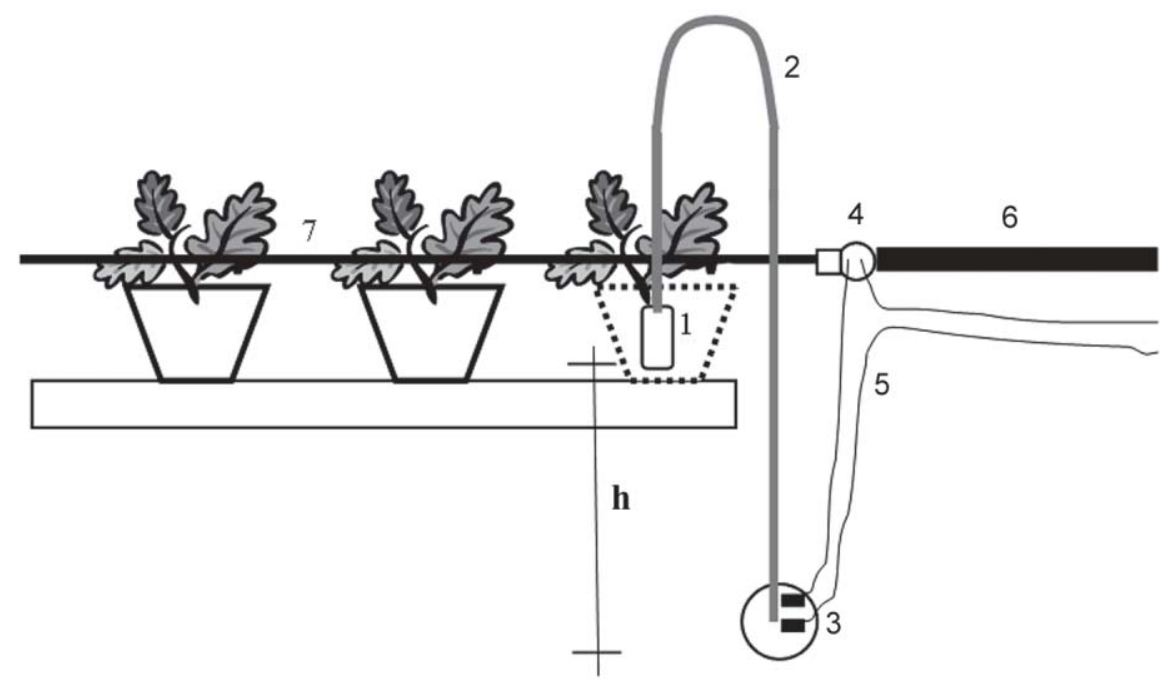

Figure 1 - Representation of the automatic irrigation controller and its use: 1 - ceramic capsule filter (tension sensor); 2 - flexible tube; 3 - pressostate from a washing machine (switcher); 4 - electromagnetic valve or water pump; 5 - electric wires; 6 - water source; 7 - drip irrigation; $h$ - vertical distance between the sensor and the switcher. 
regulável EPR-06" (Emicol Eletro Eletrônica S.A., ItúSP, Brasil). This pressostate has a key for its own adjustment and it was set to turn off the electric circuit at the lowest positive pressure (around $1 \mathrm{kPa}$ ). The water tension in the substrate was monitored by using a mercury tensiometer, which was modified in order to collect the maximum tension in the substrate near to the capsule of the watering controller, at each vertical distance " $h$ " of the controller. The modification in the tensiometer for this purpose was carried out by using the record system of the common mercury thermometer. An index and a magnetic strip from a maximum/minimum thermometer were adapted to the tensiometer to record the maximum height of its mercury ascent movement. The ceramic capsule of this modified tensiometer was placed into the substrate, touching the ceramic capsule of the watering controller. Therefore, each time the controller went on and then the irrigation was started, water entered again the capsules of both tensiometer and watering controller, so the mercury column went down and the maximum tension was recorded by the index on the magnetic strip. The drip irrigation was placed in the pots in a position that the tensiometer capsule was between the controller capsule and the water drops. After each reading, the index was pushed down with a magnet and the controller vertical distance (h) was changed.

Linear regression analyses between maximum tensions, recorded by the tensiometer, and vertical distances (h), were performed by $\mathrm{F}$ test. Each vertical distance in each substrate was tested twice.

\section{Results and Discussion}

Linear regression analysis between the maximum water tension in the substrate and the vertical distance of the watering controller was significant for commercial substrate $(p<0.0054)$ and soil $(p<0.0001)$, which were used as substrates, but the coefficient of determination was higher in soil than in the commercial substrate (Figure 2). The series of tensions were also different between the used substrates, varying from 1 to $8 \mathrm{kPa}$ in the commercial substrate, and from 4 to $13 \mathrm{kPa}$ in the soil, along with the variation of vertical distances (h) from 0.30 to $0.90 \mathrm{~m}$. The difference between commercial substrate and soil is likely to be due to the high variability of water contents in these types of commercial substrates (Marouelli et al., 2005 b).

The level of water tension kept with this automatic system is very small and could be useful to achieve the maximum yield for many plants. Smajstrla and Locascio (1996) demonstrated that irrigation should be scheduled within the 10 to $15 \mathrm{kPa}$ tension range for tomato production in Florida sandy soils. Marouelli et al. (2005 a) reported that irrigation for plants grown in substrate without soil should be started when the tension achieves 3 to $10 \mathrm{kPa}$, depending on the substrate and plant types.

In conclusion, the low cost system evaluated worked satisfactory, allowing automatic control of irrigation and adjustment of the maximum plant substrate water tension.
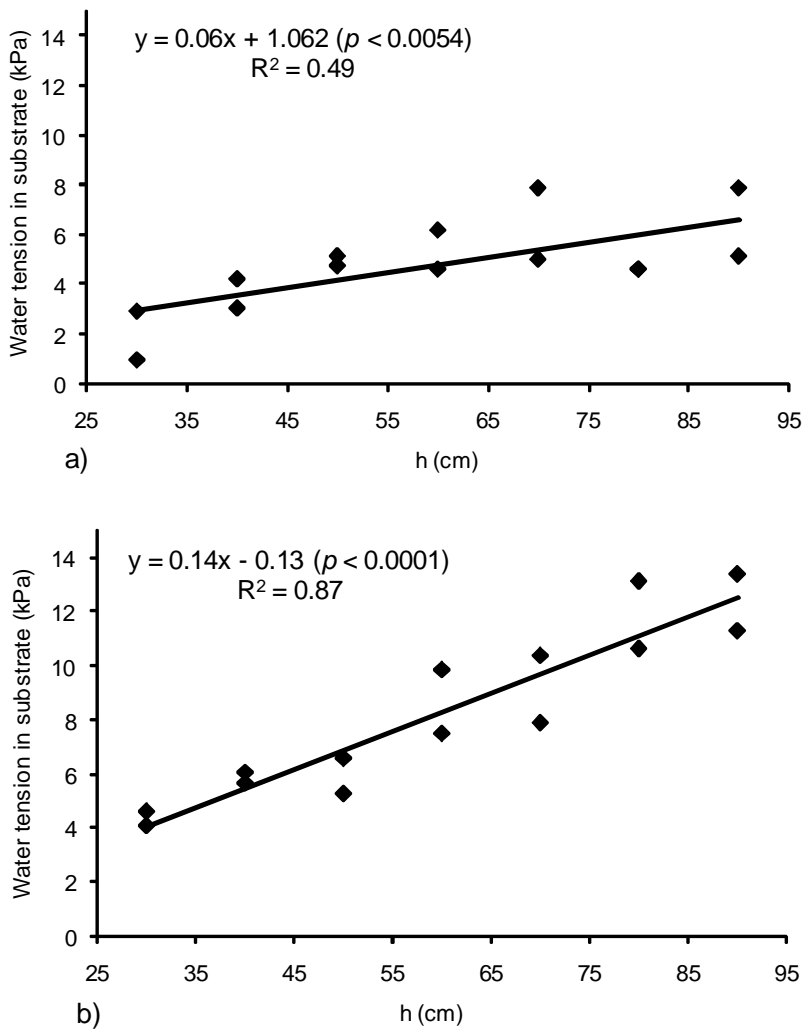

Figure 2 - Relationship between water tension in commercial substrate (a) or soil (b) and the vertical distance between the sensor and the switcher (h) of the automatic watering controller.

\section{References}

Andrews, M., Lea, P.J., Raven, J.A., Azevedo, R.A. 2009. Nitrogen use efficiency. 3. Nitrogen fixation; genes and costs. Annals of Applied Biology 155: 1-13.

Calbo, A.G. 2005. Irrigas System for Irrigation Management: Fundaments, Applications and Developments. Embrapa Hortaliças, Brasília, DF, Brazil. (in Portuguese).

Dukes, M.D.; Scholberg, J.M. 2005. Soil moisture controlled subsurface drip irrigation on sandy soils. Applied Engineering in Agriculture 21: 89-101.

Fernández, J.E.; Green, S.R.; Caspari, H.W.; Diaz-Espejo, A.; Cuevas, M.V. 2008. The use of sap flow measurements for scheduling irrigation in olive, apple and Asian pear trees and in grapevines. Plant and Soil 305: 91-104.

Lea, P.J.; Parry, M.A.J. 2008. Improving water use efficiency. Annals of Applied Biology 153: 281-282.

Lea, P.J.; Parry, M.A.J. 2009. Food security and drought. Annals of Applied Biology 155: 281-282.

Luthra, S.K.; Kaledhonkar, M.J.; Singh, O.P.; Tyagi, N.K. 1997. Design and development of an auto irrigation system. Agricultural Water Management 33: 169-181.

Marouelli, W.A.; Calbo, A.G.; Carrijo, O.A. 2005a. Evaluation of Irrigas type sensors for irrigation control in vegetables grown on substrate. Irriga 10: 88-95. (in Portuguese, with abstract in English).

Marouelli, W.A.; Carrijo, O.A.; Zolnier, S. 2005b. Spacial variability of tomato rooting system and water tension on plastic bags. Horticultura Brasileira 23: 57-60. (in Portuguese, with abstract in English).

Medici, L.O. 1995. Automatic controller for irrigation systems. Revista da Propriedade Industrial 1288: 30 (in Portuguese). 
Medici, L.O. 2008. Simplified automatic controller for irrigation systems. Revista da Propriedade Industrial 1973: 55 (in Portuguese).

Medici, L.O.; Azevedo, R.A.; Canellas, L.P.; Machado, A.T.; Pimentel, C. 2007. Stomatal conductance of maize under water and nitrogen deficits. Pesquisa Agropecuária Brasileira 42: 599601.

Queiroz, T.M.; Botrel, T.A.; Frizzone, J.A. 2008. Development of software and hardware for precision irrigation using center pivot. Engenharia Agrícola 28: 44-54. (in Portuguese, with abstract in English).

Saeed, H.; Grove, I.G.; Kettlewell, P.S.; Hall, N.W. 2008. Potential of partial rootzone drying as an alternative irrigation technique for potatoes (Solanum tuberosum). Annals of Applied Biology 152: 71-80.

Santos, A.O.; Kaye, O. 2009. Grapevine leaf water potential based upon near infrared spectroscopy. Scientia Agricola 66: 287-292.
Silva, M.M.; Libardi, P.L.; Fernandes, F.C.S. 2009. Nitrogen doses and water balance components at phenological stages of corn. Scientia Agricola 66: 515-521.

Silva, W.A.; Medici, L.O.; Carvalho, D.F.; Ceddia, M.B.; Pereira, M.G. 2001. Evaluation of a low-cost system for irrigation management. Engenharia Rural 12: 29-33. (in Portuguese, with abstract in English)

Smajstrla, A.G.; Locascio, S.J. 1996. Tensiometer-controlled, dripirrigation scheduling of tomato. Applied Engineering in Agriculture 12: 315-319.

Souza, C.F.; Folegatti, M.V. 2010. Spatial and temporal characterization of water and solute distribution patterns. Scientia Agricola 67: 9-15.

Received October 21, 2009

Accepted May 19, 2010 